\title{
PERBEDAAN JUMLAH KALSIUM OKSALAT URINE METODE SEDIMENTASI ANTARA KELOMPOK VEGETARIAN DENGAN NON - VEGETARIAN
}

Subhan $^{1}$, Erna Kristinawati ${ }^{2}$, I Wayan Getas ${ }^{3}$

${ }^{1-3}$ Jurusan Analis Kesehatan, Poltekkes Kemenkes Mataram, Indonesia

\begin{tabular}{l} 
Article Info \\
\hline Article history: \\
Received Apr 04 $4^{\text {th }}, 2019$ \\
Revised Jun $14^{\text {th }}, 2019$ \\
Accepted Jul $18^{\text {th }}, 2019$
\end{tabular}

\section{Keyword:}

Kristal Oksalat Vegetarian

Non-vegetarian

\begin{abstract}
Vegetarianism is known as a unique diet because almost all of its food comes from plants such as vegetables, fruits, grains, and nuts. For a vegetarian, meat and other natural products are foods that are not consumed. Objective to determine the amount of urine calcium oxalate sedimentation method between groups of vegetarians with Non-vegetarians. This study was carried out with an analytical Obsevational research design. Based on the time this research is cross sectional, observing and collecting data at the same time, meaning that each research subject is only observed once and the measurements are made on the character status or subject variable at the time of examination. Data analysis using non-parametric test is using the Mann Whitney test (U-Test), which is used to test two different samples with the Ordinal data form, with a confidence level of $95 \%(\alpha=0.05)$. Results: Obtained oxalate crystals in the urine of a vegetarian group, ie 15 urine samples, of which 9 (60\%) positive samples contained oxalate crystals, and $6(40 \%)$ samples did not contain oxalate crystals but only epithelial cells. Whereas, in 15 (100\%) Urine samples the Non-Vegetarian group negative samples contained oxalate crystals. There is a difference in the amount of urine oxalate crystals sedimentation method between vegetarian groups and non-vegetarians.
\end{abstract}

Copyright $@$ Jurnal Analis Medika Bio Sains All rights reserved.

\section{ABSTRAK}

Vegetarian dikenal dengan pola makan yang unik karena hampir seluruh makanannya berasal dari tumbuh tumbuhan seperti sayur, buah, padi-padian, dan kacang - kacangan. Tujuan untuk mengetahui jumlah kalsium oksalat urine metode sedimentasi antara kelompok vegetarian dengan Non-vegetarian. Metode Penelitian ini dilaksanakan dengan desain penelitian Obsevational Analitik. Berdasarkan waktunya penelitian ini bersifat cross sectional, melakukan observasi dan pengumpulan data sekaligus pada waktu yang sama, artinya tiap subjek penelitian hanya diobservasi sekali saja dan pengukuran dilakukan terhadap status karakter atau variabel subjek pada saat pemeriksaan. Analisis data menggunakan uji non parametric yaitu menggunakan uji Mann Whitney (U-Test), yang digunakan untuk menguji dua sampel yang berbeda dengan bentuk data Ordinal, dengan tingkat kepercayaan $95 \%(\alpha=0,05)$. Didapatkan kristal oksalat dalam urine kelompok vegetarian, yaitu 15 sampel urine, dimana 9 (60\%) sampel positif mengandung kristal oksalat, dan $6(40 \%)$ sampel tidak mengandung kristal oksalat melainkan hanya sel epitel. Sedangkan, pada $15(100 \%)$ sampel Urine kelompok Non-Vegetarian sampel negatif mengandung kristal oksalat. Ada Perbedaan jumlah kristal oksalat urine metode sedimentasi antara kelompok vegetarian dengan nonvegetarian.

Kata Kunci : Kristal Oksalat, Vegetarian, Non-vegetarian. 


\section{Pendahuluan}

Urine disebut juga kemih atau air kencing, adalah cairan yang diekskresi oleh ginjal, disimpan dalam kandung kemih, dan dikeluarkan melalui uretra. Jumlah urine sekitar 900-1500 ml/24 jam, dengan komposisi air sekitar $96 \%$ dan $4 \%$ berisi bahan-bahan yang terlarut di dalamnya seperti elektrolit dan sisa metabolisme. Adanya bahan-bahan sisa metabolisme tersebut dapat memberikan informasi tentang penyakit-penyakit yang ada. Urinalisis termasuk pemeriksaan laboratorium klinis paling tua dalam sejarah. Berasal dari Bahasa Inggris Urinalisys, terdiri dari kata Urine dan analysis yang berarti pemeriksaan urin.(Risna, 2014)

Jumlah penderita Gagal ginjal di Indonesia pada tahun 2013 sebanyak 0,2 \% dan sebanyak 0,6 \% penduduk menderita penyakit batu ginjal. Prevalensi meningkat seiring dengan bertambahnya umur dengan peningkatan tajam pada kelompok umur 35-44 tahun dibandingkan kelompok umur 25-34 tahun. Prevalensi pada laki-laki $(0,3 \%)$ lebih tinggi dari perempuan $(0,2 \%)$, prevalensi lebih tinggi terjadi pada masyarakat perdesaan $(0,3 \%)$, tidak bersekolah $(0,4 \%)$, pekerjaan wiraswasta, petani/nelayan/buruh $(0,3 \%)$, dan kuintil indeks kepemilikan terbawah dan menengah bawah masing-masing 0,3\%. Data tertinggi pada kelompok umur 65-74 tahun $(1,2 \%)$ dan umur $\geq 75$ tahun $(1,1 \%)$. Prevalensi lebih tinggi terdapat pada laki-laki $(0,8 \%)$ dibanding perempuan $(0,4 \%)$. (Riskesdas, 2013).

Prevalensi Ginjal kronis di Nusa Tenggara Barat berdasarkan diagnosis dokter pada penduduk umur $\geq$ 15 tahun didapatkan pada tahun 2013 - 2018 yakni sebesar 0,3\% - 4,0\%, dimana mengalami peningkatan yang signifikan, sedangkan untuk penyakit batu ginjal di Nusa Tenggara Barat Masih belum banyak dilaporkan (Kementrian kesehatan RI, 2018).

Pembentukan kristal penyebab penumpukan di ginjal berkaitan dengan konsentrasi berbagai garam di urin yang berhubungan dengan metabolisme makanan dan asupan cairan serta dampak dari perubahan yang terjadi dalam urin seperti perubahan $\mathrm{pH}$ dan suhu, yang mengubah kelarutan garam dalam air seni dalam menghasilkan pembentukan kristal. (Sulistiyowati,Dkk 2013).

Masyarakat saat ini telah menyadari bagaimana eratnya kaitan pola makanan dengan kesehatan yang baik serta pencegahan penyakit seperti penyakit degeneratif yang menyebabkan bergantinya pilihan diet yang awalnya daging menjadi sayur-sayuran yang dikenal dengan vegetarian. Hal ini dibuktikan dengan terus bertambahnya vegetarian yang terdaftar di komunitas Indonesia Vegetarian Society (IVS) yang pada tahun 1998 sebanyak 5.000 orang dan pada tahun 2000 meningkat menjadi 60.000 orang. (Ginta S, 2015).

Vegetarian dikenal sebagian orang dengan pola makan yang unik karena hampir seluruh makanannya berasal dari tumbuh-tumbuhan seperti sayur, buah, padi-padian, dan kacang - kacangan. Bagi seorang vegetarian, daging dan produk alami lainnya adalah makanan yang tidak untuk dikonsumsi (Harry, P.,2010). Vegetarian yang tinggal di negara maju umumnya memiliki mutu kesehatan yang baik salah satunya adalah angka obesitas yang rendah, serta angka kejadian penyakit jantung dan diabetes yang rendah. Namun , pada kejadian ini seorang vegetarian banyak mengkonsumsi buah dan sayur. Contoh sayur bayam misalnya, bayam (Amaranthus hybridus L.) adalah tanaman dengan kandungan asam oksalat yang sangat tinggi.

Pemeriksaan urine dilakukan dengan pemeriksan kimia, makroskopis dan mikroskopis (Mc Pherson, 2011). Pemeriksaan Kimia meliputi pemeriksaan berat jenis (BJ), pH, darah, esterase lekosit, nitrit, protein, glukosa, keton, bilirubin, dan urobilirubin. Pemeriksaan makroskopis meliputi volume, warna, kejernihan, berat jenis, bau serta $\mathrm{pH}$ urine,dan pemeriksaan mikroskopis meliputi sedimen urine.

Sedimen dalam urine mengarah pada batu ginjal yakni kristal kalsium oksalat. Kristal kalsium oksalat dan adanya predisposisi antara lain infeksi, memungkinkan timbulnya penyakit "kencing batu", yaitu terbentuknya batu ginjal-saluran kemih (lithiasis) di sepanjang ginjal saluran kemih, menimbulkan jejas, dan dapat menyebabkan fragmen sel epitel terkelupas. Pembentukan batu dapat disertai kristaluria, dan penemuan kristaluria tidak harus disertai pembentukan batu. Senyawa ini berupa kristal yang terendap dalam jaringan yang dapat menyebabkan rasa sakit yang luar biasa. (Indrawati B, 2013).

Kalsium oksalat sebagai penyebab sekitar $80 \%$ penyakit batu ginjal pada orang dewasa. Kalsium oksalat menyebabkan hiperkalsiuria dan resorbsi kalsium sehingga menyebabkan hiperkalsium yang dapat menimbulkan batu kalsium oksalat. (Yunus and Yuniarti, 2016). Namun, pada masyarakat vegetarian belum ada pelaporan mengenai gambaran jumlah kalsium oksalat urine, oleh karena itu perlu adanya penelitian mengenai perbedaan jumlah kalsium oksalat urine metode sedimentasi antara kelompok vegetarian dengan non-vegetarian. 


\section{Metode Penelitian}

Penelitian ini merupakan penelitian Obsevational Analitik. Berdasarkan waktunya penelitian ini bersifat cross sectional, melakukan observasi dan pengumpulan data sekaligus pada waktu yang sama, artinya tiap subjek penelitian hanya diobservasi sekali saja dan pengukuran dilakukan terhadap status karakter atau variabel subjek pada saat pemeriksaan. Analisis data menggunakan uji non parametric yaitu menggunakan uji Mann Whitney (U-Test), yang digunakan untuk menguji dua sampel yang berbeda dengan bentuk data Ordinal, dengan tingkat kepercayaan 95\% $(\alpha=0,05)$. Sampel yang digunakan sebanyak 30 sampel menggunakan metode random atau secara acak, diantaranya 15 sampel warga yang termasuk dalam kelompok vegetarian dan 15 sampel desa geri tembesi (non- vegetarian).

Pemeriksaan sedimen urin merupakan salah satu jenis pemeriksaan rutin,yaitu suatu jenis pemeriksaan yang menggunakan metode mikroskopik menggunakan instrumen mikroskop. Pada pemeriksaan sedimen urine jumlah unsur sedimen yang bermakna perlapangan penglihatan khususnya jenis pemeriksaan kristal urin dan unsur- unsur non-organik yang menyusun kristal urin harus dilaporkan

\section{Hasil Penelitian}

Berdasarkan penelitian yang dilakukan, didapatkan hasil pemeriksaan sedimen urine pada kelompok vegetarian. Hasil pemeriksaan sedimen urine kelompok vegetarian dapat dilihat pada tabel 1 .

Tabel 1. Hasil Pemeriksaan Sedimen urine pada kelompok vegetarian

\begin{tabular}{c|cc}
\hline \multirow{2}{*}{ Kelompok vegetarian } & \multicolumn{2}{|c}{ Kalsium Oksalat } \\
\cline { 2 - 3 } & \multicolumn{2}{|c}{ Jumlah } \\
\hline Positif & 9 & $60 \%$ \\
\hline Negatif & 6 & $40 \%$ \\
\hline Total & & $100 \%$ \\
\hline
\end{tabular}

Berdasarkan tabel 1 menunjukkan bahwa keberadaan kristal oksalat dalam urine kelompok vegetarian, yaitu sebanyak 15 sampel terdapat hasil positif yaitu sebanyak 9 sampel $(60 \%)$ terdapat kristal oksalat dalam urine tersebut dan sebanyak 6 sampel (40\%) tidak terdapat kristal oksalat dalam urine, hanya berupa sel epitel saja. Sedangkan, hasil pemeriksaan analisa sedimen urine pada kelompok non-vegetarian dapat dilihat pada tabel 2 di bawah ini.

Tabel 2. Hasil Pemeriksaan Sedimen urine kelompok non-vegetarian Desa Giri Tembisi, Lombok Barat

\begin{tabular}{c|cc}
\hline \multirow{2}{*}{ Kelompok non-vegetarian } & \multicolumn{2}{|c}{ Kalsium Oksalat } \\
\cline { 2 - 3 } & Jumlah & Rerata \\
\hline Positif & 0 & $0 \%$ \\
\hline Negatif & 15 & $100 \%$ \\
\hline Total & 15 & $100 \%$ \\
\hline
\end{tabular}

Tabel 4.2 menunjukkan bahwa keberadaan kristal oksalat dalam urine kelompok non- vegetarian, yaitu sebanyak 15 sampel $(100 \%)$ tidak terdapat kristal oksalat dalam urine tersebut. Hasil perbedaaan analisa sedimen urine pada kelompok vegetarian dengan non-vegetarian dapat dilihat pada tabel 3 dibawah ini : 
Tabel 3 Hasil perbedaan pemeriksaan sedimentasi urine antara kelompok vegetarian dengan non - vegetarian

\begin{tabular}{c|cc|cc}
\hline \multirow{2}{*}{ kalsium oksalat } & \multicolumn{2}{|c|}{ vegetarian } & \multicolumn{2}{c}{ non - vegetarian } \\
& Jumlah & $(\%)$ & (orang) & $(\%)$ \\
\hline Positif & 9 & $60 \%$ & 0 & $100 \%$ \\
\hline Negatif & 6 & $40 \%$ & 15 & $100 \%$ \\
\hline Total & 15 & $100 \%$ & 15 & \\
\hline
\end{tabular}

Tabel 3 menunjukkan bahwa keberadaan kristal oksalat dalam urine kelompok vegetarian, yaitu sebanyak 9 sampel $(60 \%)$ terdapat positif kristal oksalat, dan 6 sampel (40\%) negatif hanya terdapat sel epitel. Sedangkan keberadaan kristal oksalat dalam urine kelompok non-vegetarian, yaitu sebanyak 15 sampel $(100 \%)$ tidak terdapat kristal oksalat dalam urine.

Untuk mengetahui jumlah perbedaan kristal oksalat urine antara kelompok vegetarian dengan nonvegetarian dilakukan analisis data dengan uji statistik mann whitney test. Adapun hasil uji mann whitney test dapat dilihat pada tabel 4 .

Tabel 4. hasil uji Mann Whitney Test

\begin{tabular}{c|c|c}
\hline Variabel & Jumlah & P \\
\hline Vegetarian & & \\
- Hasil positif & 60 & \\
- Hasil negatif & 40 & \multirow{2}{*}{0.004} \\
\hline Non-vegetarian & & \\
- Hasil positif & 0 & \\
- Hasil negatif & 100 & \\
\hline
\end{tabular}

Signifikan $\mathrm{p}<0.05$

Berdasarkan hasil uji statistik dengan uji Mann Whitney Test pada tabel 4.4 di atas, hasil identifikasi keberadaan kristal oksalat urine pada kelompok vegetarian dengan non-vegetarian menunjukkan bahwa pada kelompok vegetarian didapatkan sebanyak 9 sampel (60\%) terdapat positif kristal oksalat, dan 6 sampel (40\%) negatif hanya terdapat sel epitel. Sedangkan keberadaan kristal oksalat dalam urine kelompok nonvegetarian, yaitu sebanyak 15 sampel (100\%) tidak terdapat kristal oksalat dalam urine, sehingga didapatkan dari uji statistik tersebut dengan probabilitas $0,004<\alpha=0,05$ artinya ada perbedaan jumlah kalsium oksalat antara kelompok vegetarian dengan non-vegetarian.

\section{Pembahasan}

Penelitian ini dilakukan untuk mengetahui perbedaan jumlah kalsium oksalat pada sedimen urine antara kelompok vegetarian dengan non-vegetarian. Sampel yang digunakan sebanyak 30 sampel menggunakan metode random atau secara acak, diantaranya 15 sampel warga yang termasuk dalam kelompok vegetarian dan 15 sampel desa geri tembesi (non- vegetarian). Pemeriksaan sedimen urin merupakan salah satu jenis pemeriksaan rutin,yaitu suatu jenis pemeriksaan yang menggunakan metode mikroskopik menggunakan instrumen mikroskop. Pada pemeriksaan sedimen urine jumlah unsur sedimen yang bermakna per lapangan penglihatan khususnya jenis pemeriksaan kristal urin dan unsur- unsur nonorganik yang menyusun kristal urin harus dilaporkan.

Dari hasil pemeriksaan 15 sampel urine warga yang termasuk dalam kelompok vegetarian didapatkan 9 sampel $(60 \%)$ hasil pemeriksaan sedimen urine dinyatakan positif terdapat kalsium oksalat dalam urine. 6 sampel (40\%) tidak terdapat kalsium oksalat, hanya berupa sel epitel. Sedangkan, pada kelompok nonvegetarian, dimana 15 sampel warga geri tembesi $100 \%$ sampel hasil pemeriksaan dinyatakan tidak mengandung kalsium oksalat dalam urine akan tetapi ada 7 sampel urine yang mengandung sel epitel. Jadi 
dapat di lihat ada perbedaan jumlah kalsium oksalat urine antara kelompok vegetarian dengan nonvegetarian. Hasil pemeriksaan sedimen urine yang menunjukan adanya kandungan kalsium oksalat pada 60\% dari 15 sampel penelitian yang di ambil dari kelompok vegetarian "Sri Gaura Chandra Asham", Desa Giri Tembisi.

Hasil pemeriksaan ini diperkuat dengan hasil sedimen urine dari warga yang tergolong dalam nonvegetarian $100 \%$ tidak terdapat kalsium oksalat dalam urine warga, hanya berupa sel epitel saja. Sel epitel urine normal berisi tiga varietas utama sel epitel : tubular ginjal, transisi (urotelial) dan squamos. Sel-sel ini melapisi saluran kemih, tubulus dan nefron. Sel epitel renal tubular jarang ada dalam sedimen urine yang normal (0-1/lpb). Bila ada, biasanya dalam bentuk tunggal tetapi juga ditemukan berpasangan. Sel epitel squamos adalah yang termuda dari semua sel epitel, dan mudah dikenali dan sering dijumpai dalam urine karena bentuknya yang besar dan datar. Sel epitel squamos sering dijumpai pada sedimen urine.

Sedimen urine memiliki 2 unsur, yakni organik dan an-organik. Unsur organik berasal dari sesuatu organ atau jaringan antara lain epitel, eritrosit, leukosit, silinder, potongan jaringan,sperma, bakteri, parasit. Sedangkan an-organik tidak berasal dari sesuatu organ atau jaringan., melainkan dari makanan yang dicerna seperti urat amorf dan kristal. Kristal terbentuk berkaitan dengan konsentrasi berbagai garam di urine yang berhubungan dengan metabolisme makanan responden dan cairan serta dampak dari perubahan yang terjadi dalam urine setelah perubahan ph dan suhu yang mengubah kelarutan garam dalam urine dan menghasilkan pembentukan kristal.

Pembentukan kristal kalsium oksalat baik kalsium monohidrat dan dihidrat tidak selalu berkaitan dengan $\mathrm{pH}$ urin. Sekitar 50,9\% dari batu kalsium oksalat monohidrat terdapat pada urin dengan $\mathrm{pH}$ dibawah 5,5 dan 34,1\% batu kalsium dihidrat pada urin dengan $\mathrm{pH}$ dibawah 5,5 serta 41,5\% pada pH diatas 6,0 (Grases et al, 2012).

Kristal yang ditemukan pada warga kelompok vegetarian adalah jenis kristal oksalat dihidrat. Kristal dihidrat merupakan bentuk yang paling umum ditemukan. kristal kalsium dihidrat yang secara mudah dikenali, karena tidak berwarna, bentuk oktahedral atau dua piramid yang bergabung pada dasarnya atau persis seperti amplop.(Strasinger et al, 2008). Kristal yang ditemukan pada urine warga merupakan dampak dari jenis sayur yang dikonsumsi responden seperti bayam, kangkung, daun pepaya, daun singkong, sawi, labu siam dan terong. Responden beralasan mengkonsumsi sayuran tersebut karena tanaman tersebut mudah didapatkan, ada di sawah dan ladang mereka. Sayur yang dikonsumsi responden termasuk sayur yang mengandung oksalat.

Literatur dan penelitian yang dilakukan oleh Sulistiyowati tahun 2013, diperoleh data sebagai berikut, sayur yang mengandung oksalat seperti bayam, kacang panjang, buncis, kangkung, daun singkong, daun pepaya, kol, brokoli dan selada. Sawi mengandung oksalat 1336 mg/100 g, bayam $660 \mathrm{mg} / 100 \mathrm{~g}$, kedelai, brokoli dan asparagus kurang dari 100 mg/ 100 g.14). (Sulistiyowati, dkk, 2013)

Oksalat bila berikatan dengan kalsium dalam tubuh akan membentuk senyawa tidak larut dan tidak dapat diserap tubuh. Senyawa ini berupa kristal yang terendap dalam jaringan yang dapat menyebabkan rasa sakit yang luar biasa. Kalsium dan oksalat membentuk senyawa kalsium oksalat sebagai penyebab sekitar $80 \%$ penyakit batu ginjal pada orang dewasa. Oksalat menyebabkan hiperkalsiuria dan resorbsi kalsium sehingga menyebabkan hiperkalsium yang dapat menimbulkan batu kalsium oksalat. (Sulistiyowati, dkk 2013).

Penelitian sebelumnya oleh Setiani dkk tahun 2013 menegaskan bahwa hiperoksaluria meningkatkan kalsium oksalat jenuh dan berkontribusi terbentuknya batu kalsium oksalat, ekskresi oksalat urin pada wanita $45 \mathrm{mg} / \mathrm{hari}$ dan pada laki-laki $55 \mathrm{mg} /$ hari. $90 \%$ dari diet oksalat akan mengikat kalsium di usus kecil sebagai kalsium oksalat dan $10 \%$ oksalat bebas dan terserap dalam usus besar, kemudian diekskresi dalam urin.

Hiperoksaluri mungkin akibat diet tinggi oksalat, namun dapat juga terjadi pada pasien dengan malabsorsi lemak enterik.hal ini bisa terjadi karena kelebihan lemak enterik mengikat kalsium bebas dan mengakibatkan oksalat bebas lebih mudah diserap di kolon. Sebagian besar batu saluran kemih adalah kalsium oksalat, secara garis besar pembentukan oksalat berasal dari diet (oksalat eksogen) dan hasil metabolisme (oksalat endogen). Pada penelitian sebagian besar oksalat adalah endogen yaitu 85-90\%, selebihnya adalah oksalat eksogen ( Setiani,dkk 2013).

Pada penelitian sebelumnya yang dilakukan oleh Ni Gusti Ayu Sanggrayani Astadi yang berjudul "Tingkat Konsumsi Energi Protein dan Status gizi Vegetarian Di Asrama Sri Radha Gopsivara Madha Banyuning" pada tahun 2017 bahwa perbedaan konsumsi pola makan responden vegetarian dan non vegetarian terletak pada asupan konsumsi protein, dimana konsumsi asupan protein pada responden vegetarian bersumber dari kacang-kacangan seperti, tempe, tahu, soya. Sedangkan asupan susu, responden vegetarian masih ada yang mengonsumsi susu sapi dan makanan pokok semua responden adalah nasi. Sesuai penelitian yang dilakukan olehnya, menyimpulkan bahwa jenis makanan pokok yang dikonsumsi komunitas 
vegetarian adalah nasi, dan Jenis protein yang dikonsumsi oleh responden pada penelitian ini adalah protein yang berasal dari nabati dan susu sapi. Hampir 100\% responden mengkonsumsi protein jenis nabati sepeti protein yang berasal dari kacang-kacangan.

Sampel penelitian di ambil dari warga yang diatas 2 tahun menjadi vegetarian dengan rentang usia rata-rata 25 tahun - 40 tahun, untuk memudahkan mengamati adanya kristal oksalat dalam urine pada kelompok vegetarian dengan non-vegetarian dan mencegah terjadinya penyakit degeneratif yang dapat menimbulkan hasil positif palsu terhadap kristal oksalat dalam urine tersebut.

Dalam penelitian ini, peneliti hanya memeriksa sampel urine sekali saja tanpa pengecatan dengan menggunakan sampel urine pagi dan tidak membedakan jenis variatas makanan yang dikonsumsi seperti sayuran yang dikonsumsi oleh kelompok vegetarian dengan non-vegetarian tersebut, serta tidak membedakan asam \& basa urine kelompok vegetarian dengan non-vegetarian.

\section{Kesimpulan}

Jumlah rata-rata Sedimen urine pada 15 warga yang tergolong kelompok vegetarian 9 orang $(60 \%)$ terdapat kristal oksalat dalam urine dan 6 orang (40\%) tidak terdapat kalsium oksalat, hanya saja ditemukan sel epitel. Sedangkan, jumlah rata-rata sedimen urine pada 15 warga desa Geri Tembesi yang tergolong nonvegetarian $100 \%$ tidak terdapat kristal oksalat dalam Urine. Ada perbedaan jumlah kalsium oksalat urine metode sedimentasi antara kelompok vegetarian dengan non-vegetarian.

\section{Daftar Pustaka}

Agus Tessy, (2008). Buku ajaran ilmu penyakit dalam: infeksi saluran kemih. Edisi: 3. Jakarta: FKUI Alatas H. Diagnosa dan Tatalaksana Infeksi Saluran Kemih. Ed.Hot Topics in Pediatrics II. Balai Penerbit FKUI. Jakarta. 2002

Arvin, A.M.,Eds. Nelson textbook of pediatrics; 17th Ed. WB Saunders Co., Philadelphia. 2003.

Bawazier L.A. 2009. Ginjal Hipertensi: Proteinuria. Dalam: Sudoyo, A.W

Brunzel, N. A. (2018). Fundamental of Urine \& Body Fluid Analysis. China: Elsevier.

Chenari, M. R., Gooran, S., Zarghami, A., \& Fazeli, F. (2012). Assessment of Urine Analysis Diagnostic Role : A Cross-Sectional Study in South Eastern of Iran, 2012(November), 227-231.

Depkes RI, 2010. Peraturan Mentri Kesehatan RI No.32/Menkes/Per/ix/2002. Jakarta:Depkes RI

Diarti, M. W., Danuyanti, I. G. A. N. dan Ernawati, F. 2015. Diktat Praktikum Kimia Klinik I Program Studi D.IV Analis Kesehatan. Mataram : Poltekkes Mataram Kemenkes RI.

Elder, J.S. Urinary Tract Infections. In: Behman, R.E., Kliegman, R.M.

Gandasoebrata R, 2006. Pemeriksaan Urine, Penuntun Laboratorium Klinik. Jakarta: Dian Rakyat. P:35

Gandasoebrata R, 2007. Penuntun Laboratorium Klinik. Jakarta: Dian rakyat

Harrison IB. Prinsip-Prinsip Ilmu Penyakit Dalam. Edisi 13. Buku Kedokteran. EGC. Jakarta. 2000. Hal 616620

Hardjoeno H. Interpretasi Hasil Tes Laboratorium Diagnostik Edisi 5 Lembaga penerbitan Universitas Hasanuddin. 2003. Hal 40, 129

Koestadi. 1989. Kimia Klinik Teori dan Praktek Darah. Kediri: AAK Bhakti Wiyata

Kasper, D. L., Braunwald, E., Fauci, A. S., Hauser, S. L., Longo, D. L., dan Jameson, J. L. 2005. Urinary tract infection and pyelonephritis. Di dalamHarrison's Principles of Internal Medicine. Edisi: 16. New York: Mc Graw-Hill.

Kurniawan, F. B. 2014. Kimia Klinik: Praktikum Analis Kesehatan. Jakarta: EGC

Lina, Nur (2008) Faktor-Faktor Resiko Kejadian Batu Saluran Kemih pada Laki-laki (studi kasus di RS. Dr. Kariadi, RS. Roemani dan RSI Sultan Agung Semarang)

Mundt, A. L. dkk. 2011. Graff's Textbook of Routine Urinalysis and Body Fluids. Edisi 2. Philadelphia : Lippincott Williams and Wilkins.

Mc Pherson, R.A. dkk. 2011, Henry’s clinical diagnosis and management by laboratory methods, Elsevier saunders

Mundt, L. A., \& Shanahan, K. (2011). Graff's Textbook of Routine Urinalysis and Body Fluids (second). USA: WOLTERS KLUWER. 
Notoatmodjo S (2012) 'Metodologi Penelitian Kesehatan, Rineka Cipta Jakarta.'

Prodia. (2011). Pedoman Mutu Pemeriksaan Urin.

Pusparini. (2011). Pemeriksaan Urin,Feses,Sekret,dan Sperma Diksar Prodia 2011.

Rusdidjas, Ramayanti R. Infeksi Saluran Kemih. Balai Penerbit FKUI. Jakarta. 2002. Hal 127

Rubenstein. David, Bradley. John. 2007. Kedokteran Klinis. Jakarta: Erlangga

Rao, N., Srirangam, S., \& Preminger, G. (2007). Urological Tests in Clinical Practice.

Santhi, D., Dewi, R., \& AP, S. (2015). Penuntun Praktikum Kimia Klinik I. Denpasar

Strasinger, S. K. dkk. 2008. Urinalysis and Body Fluid. Edisi 5. Philadelphia : F. A. Davis Company.

Sugiono, 2011. Metodelogi Penelitian Kuantitatif, dan $R \&$ D. Alfabeta. Bandung

Susiono Herawati, 2009. Patologi Klinis Urinalisa. Jakarta: UKRIDA 